\title{
Preferensi Serangan Tikus Sawah (Rattus argentiventer) terhadap Tanaman Padi
}

\author{
The Preference of Rice Field Rat's (attus argentiventer) Attack on Rice Crops
}

\author{
Hamdan Maruli Siregar ${ }^{1 *}$, Swastiko Priyambodo ${ }^{2}$, Dadan Hindayana ${ }^{2}$
}

${ }^{1}$ Universitas Jambi, Mendalo Darat, Kecamatan. Jambi Luar Kota, Kabupaten Muaro Jambi, 36657, Indonesia

${ }^{2}$ Departemen Proteksi Tanaman, Institut Pertanian Bogor, Darmaga, Bogor, 16680, Indonesia

*Email korespondensi: HM.Siregar@unja.ac.id

Diterima: 6 Januari 2020 / Disetujui: 18 Februari 2020

\begin{abstract}
Rice field rat is one of the main pests of rice crops which is very detrimental to farmers because it can damage at all the rice crop stages. The objectives of this research is to determine the preference of rice field rat's attack based on the rice crop stages. This research was conducted at irrigated rice field of Wirakanan Village, Kandanghaur District, Indramayu Regency, West Java from January to April 2018. Rat trapping was conducted using linear trap barrier system (LTBS). LTBS was installed in the village border habitat for one growing season, which consists of 3 installation periods, i.e., vegetative stage, early generative stage, and the late generative stage. The results showed that the highest number of catches and intensities of rat's attack occurred in the early generative stage. In conclusion, the preference of rice filed rat's attack on rice crops is in the early generative stage.
\end{abstract}

Keywords: early generative stage, preference, rice crops, rice field rat

\section{ABSTRAK}

Tikus sawah adalah salah satu hama utama tanaman padi yang sangat merugikan bagi petani karena dapat merusak pada semua stadia pertumbuhan tanaman. Penelitian ini bertujuan untuk mengetahui preferensi serangan tikus sawah terhadap tanaman padi berdasarkan stadia pertumbuhannya. Penelitian dilaksanakan di lahan sawah irigasi Desa Wirakanan, Kecamatan Kandanghaur, Kabupaten Indramayu, Jawa Barat dari bulan Januari sampai April 2018. Percobaan yang dilakukan adalah pemerangkapan tikus menggunakan linear trap barrier system (LTBS). LTBS dipasang di habitat tepi kampung selama satu musim tanam yang terdiri atas 3 periode pemasangan, yaitu stadia vegetatif, stadia awal generatif, dan stadia akhir generatif. Hasil penelitian menunjukkan bahwa jumlah tangkapan tikus dan intensitas kerusakan tanaman padi tertinggi terjadi pada stadia awal generatif. Hal ini mengindikasikan bahwa preferensi serangan tikus sawah terhadap tanaman padi terjadi pada stadia awal generatif.

Kata kunci: padi, preferensi, stadia awal genertif, tikus sawah

\section{LATAR BELAKANG}

Peningkatan produktivitas tanaman padi merupakan salah satu unsur terpenting dalam upaya mewujudkan sistem ketahanan pangan nasional. Optimalisasi potensi lahan melalui peningkatan indeks pertanaman padi merupakan cara yang saat ini banyak dilakukan untuk meningkatkan produktivitas. Namun demikian, di sisi lain hal ini justru menimbulkan masalah baru yaitu meningkatnya populasi hama, salah satunya adalah populasi tikus sawah. Hasil penelitian Sudarmaji dan Herawati (2017) menunjukkan bahwa populasi tikus sawah pada pertanaman padi yang ditanam dengan indeks pertanaman 3 kali dalam setahun cenderung mengalami peningkatan pada setiap musim tanamnya. Hal ini karena peningkatan indeks pertanaman padi secara tidak langsung menyebabkan terbentuknya kondisi lingkungan yang menguntungkan bagi tikus, yaitu tersedianya sumber makanan yang melimpah, sehingga sangat mendukung proses perkembangbiakannya.

Tikus sawah merupakan salah satu hama utama tanaman padi yang hampir di setiap musim tanam selalu menyebabkan kerusakan dan kehilangan hasil panen. Pusdatin Pertanian (2018) mencatat bahwa tikus sawah adalah hama utama tanaman padi dengan tingkat serangan puso tertinggi. Luas serangan tikus sawah di Indonesia mencapai 66,087 ha/th dengan 1,852 ha diantaranya mengalami puso. Kondisi tersebut tentu sangat merugikan bagi petani karena besarnya kerusakan dan kehilangan hasil yang ditimbulkan. Hal ini bahkan menjadi acaman yang sangat serius bagi keberlanjutan usaha tani karena serangan tikus terjadi hampir di seluruh provinsi di Indonesia dan 
hanya 2 provinsi yang tidak terkena serangan, yaitu Kepulauan Riau dan Kalimantan Utara.

Beberapa tindakan pengendalian telah banyak dilakukan oleh petani, diantaranya adalah dengan cara gropyokan, pengemposan (fumigasi), penggunaan predator seperti burung hantu (Tyto alba), pemerangkapan, penggunaan rodentisida, dan bahkan dengan pemasangan pagar listrik. Meskipun demikian, faktanya hingga saat ini keberhasilan pengendalian yang dilakukan petani masih belum konsisiten dan belum ada acara pengendalian tunggal yang dapat mengatasi masalah hama tikus pada semua kondisi ekosistem (Baco, 2011).

Rendahnya pengetahuan petani mengenai sifat-sifat biologis tikus dan strategi pengendaliannya merupakan salah satu faktor yang seringkali menyebabkan ketidaktepatan tindakan pengendalian yang dilakukan oleh petani. Fakta di lapangan menunjukkan bahwa beberapa kelemahan petani dalam melakukan tindakan pengendalian tikus sawah diantaranya adalah lemahnya pengamtan terhadap keberadaan tikus, pengendalian yang bersifat individual, dan waktu tanam yang tidak serempak (Siregar et al., 2019). Oleh karena itu, pemahaman mengenai sifat-sifat biologis tikus sangat dibutuhkan sebagai pengetahuan dasar dalam melakukan tindakan pengendalian. Pengintegrasian komponen-komponen pengendalian melalui sistem pengendalian terpadu akan berhasil apabila memahami dan memperhatikan aspek bioekologi tikus dan nilai ekonomi dari kerusakan yang ditimbulkan (Baco, 2011).

Berdasarkan hal tersebut, penelitian mengenai preferensi serangan tikus sawah terhadap tanaman padi sangat penting dilakukan untuk mengetahui tingkat serangan tikus yang terjadi pada setiap stadia pertumbuhan tanaman padi. Dengan demikian, informasi tersebut dapat digunakan sebagai dasar dalam menentukan waktu dan tindakan pengendalian yang tepat.

\section{BAHAN DAN METODE}

Penelitian ini dilaksanakan di Desa Wirakanan, Kecamatan Kandanghaur, Kabupaten Indramayu, Jawa Barat dari bulan Januari sampai April 2018. Lokasi penelitian merupakan satu hamparan sawah irigasi yang berbatasan langsung dengan habitat utama tikus sawah, yaitu tepi kampung. Percobaan yang dilakukan pada penelitian ini adalah pemasangan 3 unit LTBS di habitat tepi kampung (Gambar 1). LTBS dipasang selama satu musim tanam yang terdiri dari 3 periode pemasangan, yaitu pada stadia vegetatif yang dimulai 7 hari setelah tanam sampai anakan maksimum, stadia awal generatif dimulai saat primordia sampai pembungaan, dan stadia akhir generatif dimulai saat matang susu sampai panen. Pada setiap periode pemasangan LTBS dipasang selama 25 hari dan kemudian dipindah sejauh $200 \mathrm{~m}$ dari posisi awal pemasangan.
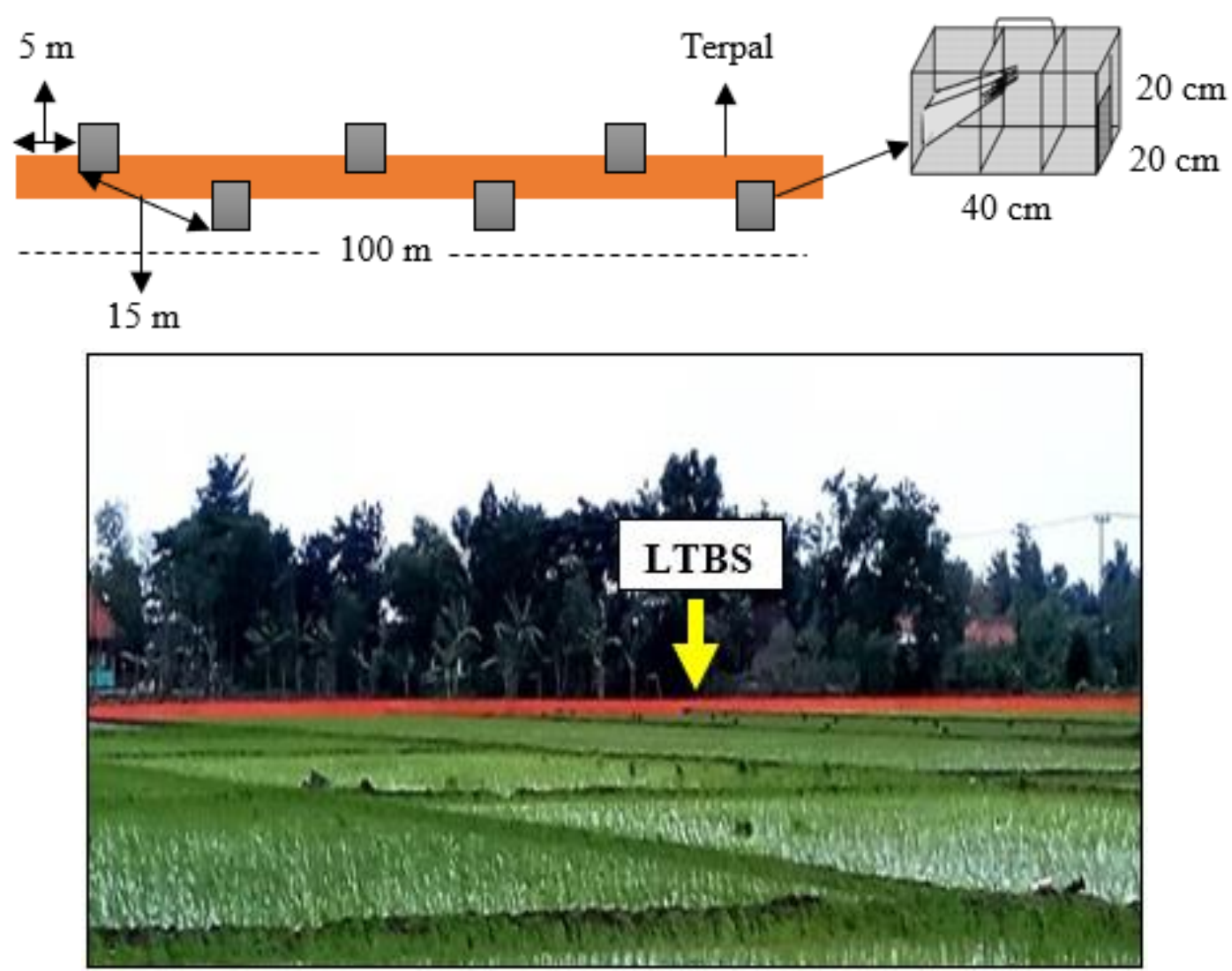

Gambar 1. Skema pemasangan LTBS di habitat tepi kampung 
Variabel yang diamati pada penelitian ini adalah komposisi tangkapan, jumlah tangkapan, dan intensitas kerusakan tanaman padi. Pengamatan hasil tangkapan LTBS dilakukan setiap hari pada setiap periode pemasangan LTBS dengan cara menghitung dan mengidentifikkasinya. Sementara itu, pengamatan terhadap intensitas kerusakan tanaman padi dilakukan dengan pengambilan sampel rumpun padi secara sistematis menggunakan metode double diagonal yang merupakan modifikasi dari metode irisan diagonal. Pengamatan ini dilakukan dengan cara menghitung jumlah anakan yang terserang dan tidak terserang pada setiap sampel rumpun padi. Jumlah sampel rumpun padi yang diamati adalah sebanyak 50 rumpun yang terbagi menjadi 2 bagian, yaitu 25 sampel rumpun untuk setiap irisan diagonal. Berikut adalah rumus yang digunakan untuk menghitung intensitas kerusakan tanaman padi, yaitu:

$$
\mathbf{I}=\frac{a}{a+b} \times 100 \%
$$

Keterangan : I : intensitas kerusakan (\%)

a : jumlah anakan terserang

b : jumlah anakan tidak terserang

Data hasil tangkapan LTBS dan intensitas kerusakan tanaman padi kemudian diolah dalam bentuk tabulasi data dan analisis regresi menggunakan Microsoft Excel 2013.

\section{HASIL DAN PEMBAHASAN}

\section{Komposisi Tangkapan LTBS}

LTBS adalah alat perangkap tikus yang dibuat menggunakan sistem bubu perangkap dan merupakan hasil modifikasi dari Community Trap Barrier System (CTBS). Salah satu yang membedakannya adalah pada LTBS tidak menggunakan tanaman perangkap. LTBS dirancang agar mudah dipindah tempatkan ke lokasi lain apabila jumlah tangkapan pada suatu lokasi sudah menurun atau bahkan tidak ada lagi tangkapan.

Hasil pemasangan LTBS di habitat tepi kampung menunjukkan komposisi tangkapan yang cukup beragam. Beberapa organisme yang tertangkap diantaranya adalah tikus sawah, tikus wirok, tikus rumah, cecurut, ular, katak, dan burung (Tabel 1). Keberagaman hasil tangkapan ini terjadi karena ekosistem sawah irigasi dihuni oleh beragam organisme yang saling berinteraksi membentuk suatu siklus energi yang berpengaruh terhadap keseimbangan dan produktivitas ekosistem. Salah satunya adalah predasi, yaitu interaksi yang terjadi antara pemangsa (ular) dan mangsanya (tikus) melalui proses rantai makanan. Hal ini sangatlah penting karena tanpa adanya interaksi yang seimbang antar komponen penyusun ekosistem maka akan muncul permasalahan baru, salah satunya adalah serangan hama (Fitriani, 2016).

Berdasarkan data komposisi hasil tangkapan LTBS diketahui bahwa tikus sawah adalah organisme yang paling banyak tertangkap, yaitu 81.45\% (202 ekor) (Tabel 1). Hal ini karena tikus sawah adalah hama utama tanaman padi dan merupakan spesies yang paling dominan berperan sebagai hama pada tanaman padi (Jacob et al., 2010). Tikus lebih menyukai padi (gabah) dibandingkan dengan jenis pakan lainnya (beras dan jagung) karena gabah memiliki lapisan kulit yang relatif lebih keras dan tikus memanfaatkannya untuk mengurangi pertumbuhan gigi serinya yang tumbuh terus menerus (Priyambodo dan Nazarreta, 2013).

Di samping itu, hal tersebut juga menunjukkan bahwa penggunaan bubu perangkap sebagai salah satu teknik pengendalian hama tikus berfungsi cukup efektif. Keefektifan ini ditunjukkan oleh banyaknya jumlah tangkapan dan rendahnya intensitas kerusakan yang terjadi. Meskipun demikian, penggunaan LTBS sebagai salah satu teknik pengendalian hama tikus tidak dapat secara menyeluruh melindungi pertanaman padi dari serangan tikus karena LTBS hanya dipasang pada satu sisi lahan, sehingga tikus yang berasal dari sisi lain masih dapat masuk dan merusak pertanaman padi (Sudartik, 2015).

\section{Jumlah Tangkapan Tikus Sawah dan Intensitas Kerusakan Tanaman Padi}

Variabel yang digunakan untuk menganalisis preferensi serangan tikus pada tanaman padi adalah jumlah tangkapan tikus dan intensitas kerusakan tanaman padi yang terjadi pada setiap periode pemasangan LTBS. Semakin banyak jumlah tangkapan tikus dan semakin tinggi intensitas kerusakan yang terjadi pada suatu periode pemerangkapan tertentu mengindikasikan bahwa tikus memiliki preferensi terhadap stadia pertumbuhan tersebut.

Hasil pengamatan terhadap jumlah tangkapan harian tikus menunjukkan bahwa terdapat fluktuasi jumlah tangkapan pada setiap periode pemerangkapan (Gambar 2). Hal ini tentu sangat dipengaruhi oleh kelimpahan populasi tikus, kondisi lingkungan, dan aktivitas harian tikus yang terjadi pada setiap periode pemerangkapan. Dalam melakukan aktivitasnya, tikus didukung oleh kemampuan indra yang berkembang dengan sangat baik, khususnya adalah indra penciuman, pendengaran, perasa, dan peraba. Oleh karena itu, tikus sangat sensitif dan merespon terhadap setiap perubahan yang terjadi di ekosistem tempat tinggalnya termasuk perubahan kondisi lingkungan yang terjadi pada setiap stadia pertumbuhan tanaman padi (Benedek dan Sirbu, 2018).

Selain itu, pemindahan lokasi pemerangkapan pada setiap stadia pertumbuhan tanaman padi juga memungkinkan adanya perbedaan kelimpahan populasi tikus pada setiap lokasi pemerangkapan. LIU (2019) menyatakan bahwa tingkat kelahiran, kematian, imigrasi, dan emigrasi merupakan faktor yang sangat mempengaruhi kelimpahan populasi tikus. Keberadaan tikus pada suatu lokasi biasanya ditandai dengan adanya jejak kaki (foot print), kotoran, jalur jalan (run way), dan sarang aktif. Meskipun demikian, pada lokasi pemasangan LTBS yang tidak terdeteksi adanya tanda keberadan tikus tetap mendapatkan hasil tangkapan karena tikus dapat bergerak hingga $700 \mathrm{~m}$ dari sarangnya untuk mencari pakan (Priyambodo, 2009). 
Tabel 1. Komposisi hasil tangkapan LTBS di habitat tepi kampung

\begin{tabular}{lcc}
\hline Organisme Tangkapan & Jumlah Tangkapan (ekor) & $\%$ \\
\hline Tikus Sawah & 202 & 81.45 \\
Tikus Wirok & 3 & 1.21 \\
Tikus Rumah & 2 & 0.81 \\
Cecurut & 19 & 7.66 \\
Ular & 15 & 6.05 \\
Katak & 6 & 2.42 \\
Burung & 1 & 0.40 \\
\hline
\end{tabular}

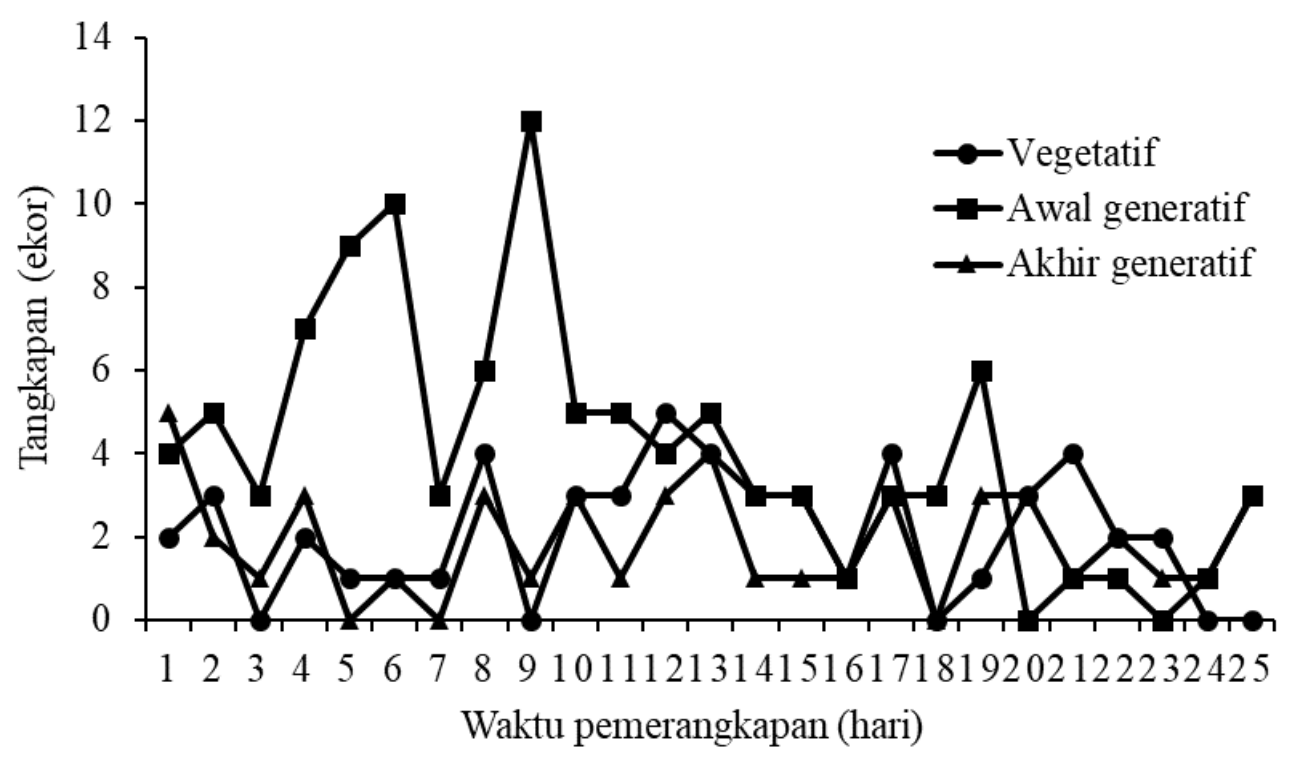

Gambar 2. Tangkapan harian tikus sawah berdasarkan periode pemasangan LTBS

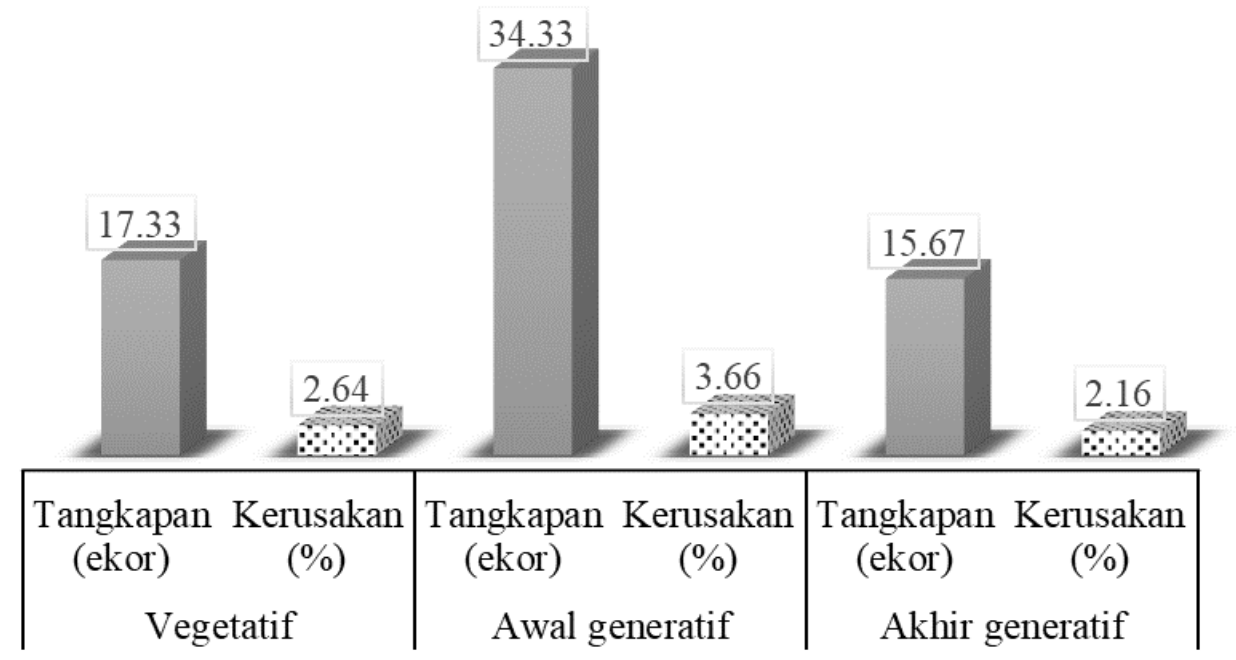

Gambar 3. Rata-rata jumlah tangkapan tikus sawah dan intensitas kerusakan tanaman padi 


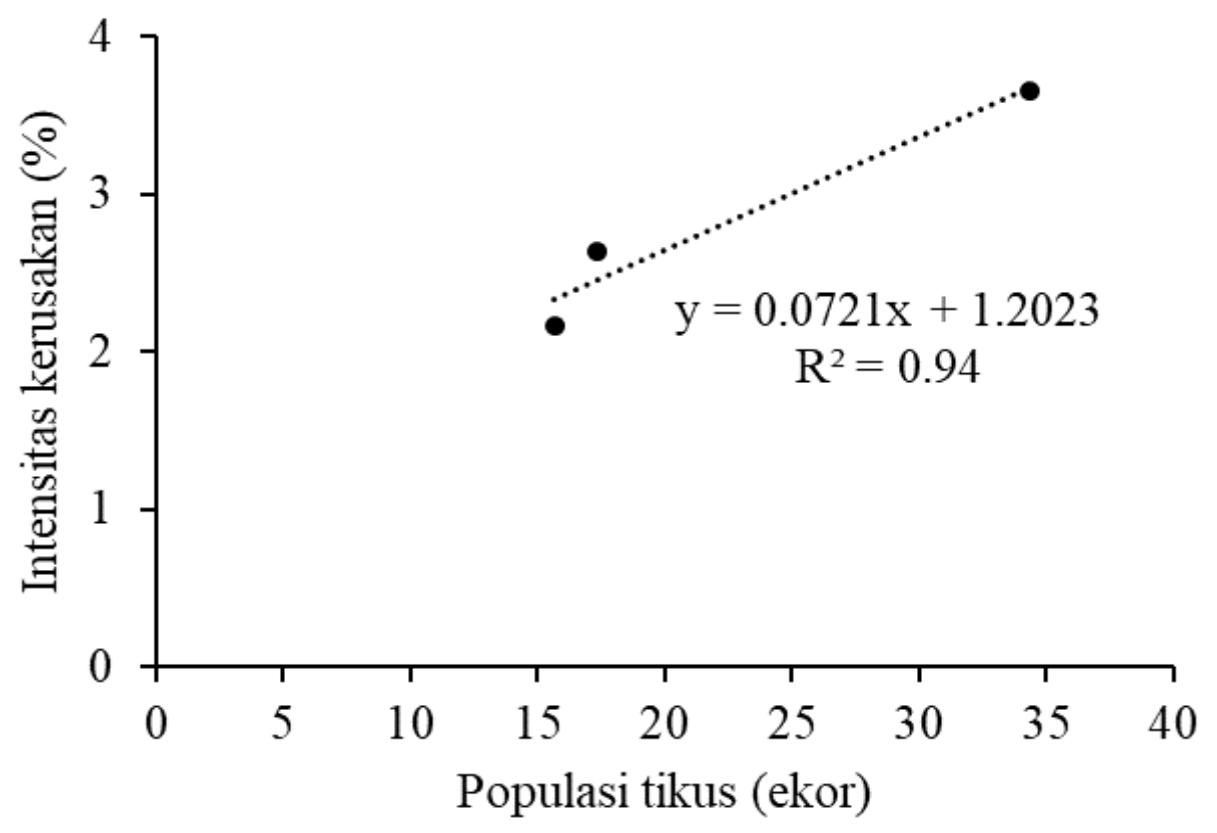

Gambar 4. Hubungan antara populasi tikus sawah dan intensitas kerusakan tanaman padi.

Namun demikian apabila dilihat berdasarkan periode pemerangkapannya, rata-rata jumlah tangkapan tikus dan intensitas kerusakannya menunjukkan pola yang relatif sama, yaitu rata-rata jumlah tangkapan dan intensitas kerusakan tertinggi terjadi pada stadia awal generatif. Sebaliknya pada stadia vegetatif dan akhir generatif yang rata-rata jumlah tangkapan tikus dan intensitas kerusakannya relatif lebih rendah (Gambar 3). Hasil ini mengindikasikan bahwa preferensi serangan tikus pada tanaman padi cenderung terjadi pada stadia awal generatif. Tingginya daya tarik tikus terhadap stadia awal generatif diduga karena adanya beberapa aroma senyawa volatil yang terkandung pada tanaman padi yang sangat disukai oleh tikus (Mardiah dan Sudarmaji, 2012).

Ketersediaan sumber makanan yang melimpah dengan kualitas baik merupakan faktor pendukung bagi tikus untuk berkembangbiak secara optimal (Htwe et al., 2012) dan padi stadia stadia bunting merupakan pakan yang paling disukai oleh tikus (Mardiah dan Sudarmaji, 2012). Hal ini sejalan dengan proses perkembangbiakan tikus yang juga dimulai pada saat tanaman padi memasuki stadia generatif. Oleh karena itu, untuk mendukung proses perkembangbiakannya tikus membutuhkan pakan yang berkualitas sebagaimana yang terkandung pada padi stadia bunting. Kondisi inilah yang kemudian menyebabkan aktivitas pergerakan tikus lebih banyak terjadi pada stadia awal generatif dan salah satu tanda aktivitasnya adalah adanya gejala serangan berupa kerusakan pada tanaman padi.

Hubungan Populasi Tikus Sawah dan Intensitas Kerusakan Tanaman Padi
Pada umumnya intensitas kerusakan tanaman padi akibat serangan tikus sangat dipengaruhi oleh kelimpahan populasi tikus. Semakin tinggi populasi tikus, maka semakin tinggi pula kemungkinan intensitas kerusakan yang terjadi. Pada pembahasan ini, tingkat populasi tikus digambarkan oleh banyaknya jumlah tangkapan tikus yang didapatkan pada setiap periode pemerangkapan. Hasil analisis regresi menunjukkan bahwa jumlah tangkapan tikus memiliki hubungan yang positif terhadap intensitas kerusakan yang terjadi. Nilai koefisien determinasi $\left(\mathrm{R}^{2}=0.94\right)$ berarti bahwa 94\% intensitas kerusakan tanaman padi akibat serangan tikus ditentukan oleh tingkat populasi tikus (Gambar 4).

Selain itu, tingginya intensitas kerusakan tanaman padi akibat serangan tikus terjadi karena tikus memiliki kemampuan yang lebih dibandingkan kelompok hama lainnya, diantaranya adalah memiliki mobilitas tinggi, merusak pada semua stadia pertumbuhan tanaman, merusak dalam waktu singkat, dan pada tingkat serangan yang tinggi tikus dapat merusak semua rumpun padi dan hanya menyisakan 1-2 baris rumpun pada bagian pinggir (Kementan, 2013). Kondisi ini bahkan semakin berbahaya karena daya rusak tikus terhadap terhadap tanaman padi 5 kali lebih besar dari jumlah yang dikonsumsi (Priyambodo, 2009).

\section{KESIMPULAN}

Berdasarkan hasil dan pembahasan di atas dapat disimpulkan bahwa preferensi serangan tikus sawah terhadap tanaman padi terjadi pada stadia awal generatif. Hal ini ditandai dengan banyaknya jumlah tangkapan dan tingginya tingkat kerusakan tanaman padi yang terjadi pada stadia awal generatif dibandingkan pada stadia vegetatif dan akhir generatif yang cenderung relatif lebih rendah. 


\section{DAFTAR PUSTAKA}

Baco, D. (2011). Pengendalian tikus pada tanaman padi melalui pendekatan ekologi. Pengembangan Inovasi Pertanian, 4(1), 47-62.

Benedek, A. M., \& Sîrbu, I. (2018). Responses of small mammal communities to environment and agriculture in a rural mosaic landscape. Mammalian Biology, 90, $55-65$.

https://doi.org/10.1016/j.mambio.2018.02.008.

Fitriani. (2016). Keanekaragaman Arthropoda pada ekosistem tanaman padi dengan aplikasi pestisida. Agrovital, 1(1), 6-8. http://dx.doi.org/10.35329/agrovital.v1i1.77.

Htwe, N. M., Singleton, G. R., Hinds, L. A., Propper, C. R., \& Sluydts, V. (2012). Breeding ecology of rice field rats, Rattus argentiventer and $R$. tanezumi in lowland irrigated rice systems in the Philippines. Agriculture, Ecosystems \& Environment, 161, 39-45. https://doi.org/10.1016/j.agee.2012.07.023.

Jacob, J., Sudarmaji, Singleton, G. R., Rahmini, Herawati, N. A., \& Brown, P. R. (2010). Ecologically based management of rodents in lowland irrigated rice fields in Indonesia. Wildlife Research, 37(5), 418427. https://doi.org/10.1071/WR10030.

Kementerian Pertanian (Kementan). (2013). Pedoman Rekomendasi Pengendalian Organisme Pengganggu Tumbuhan (OPT) Tanaman Serealia. Jakarta: Direktorat Jenderal Tanaman Pagan.

LIU, X. (2019). Rodent biology and management: Current status, opinion and challenges in China. Journal of Integrative Agriculture, 18(4), 830-839. https://doi.org/10.1016/S2095-3119(18)61943-4.

Mardiah, Z., \& Sudarmaji. (2012). Identifikasi komponen volatil tanaman padi fase bunting dan matang susu sebagai pakan alami yang disukai tikus sawah. Penelitian Pertanian Tanaman Pangan, 31(2), 100107.

http://dx.doi.org/10.21082/jpptp.v31n2.2012.p\%25p.

Priyambodo, S. (2009). Pengendalian Hama Tikus Terpadu. Jakarta: Penebar Swadaya.

Priyambodo, S., \& Nazarreta, R. (2013). Preferensi dan efikasi rodentisida brodifakum terhadap tiga jenis tikus hama. Agrovigor, 6(2), 145-153. https://doi.org/10.21107/agrovigor.v6i2.1490.

Pusat Data dan Sistem Informasi Pertanian (Pusdatin Pertanian). (2018). Statistik iklim, organisme pengganggu tanaman dan dampak perubahan iklim 2015-2018. Sekertariat Jenderal, Kementerian Pertanian. http://epublikasi.setjen.pertanian.go.id [22 November 2019].

Siregar, H. M., Priyambodo. S., \& Hindayana, D. (2019). Hubungan tingkat pengetahuan, sikap, dan tindakan petani dalam penerapan pengendalian hama tikus terpadu di ekosistem sawah irigasi. hal. 31-439. Dalam Irianto., Junedi, H., Nusifera, S., Fathoni, Z (Eds.). Prosiding Semirata BKS-PTN Wilayah Barat Bidang Ilmu Pertanian: Inovasi Pertanian Berbasis Sumberdaya Lokal Berorientasi Entrepreneurship. Jambi 27-29 Agustus 2019.

Sudarmaji., dan Herawati, N. A. (2017). Perkembangan populasi tikus sawah pada lahan sawah irigasi dalam pola indeks pertanaman padi 300. Penelitian Pertanian Tanaman Pangan, 1(2), 125-131. http://dx.doi.org/10.21082/jpptp.v1n2.2017.p125131.

Sudartik, E. (2015). Keefektifan tiga teknik pengendalian tikus sawah (Rattus argentiventer Rob \& Kloss) di Desa Murante, Kecamatan Suli, Kabupaten Luwu. Perbal, $4(1)$. 